\title{
Discrimination and abundance estimation of wild and released abalone Haliotis diversicolor using stable carbon and oxygen isotope analysis in north-eastern Taiwan
}

\author{
YIng-Chou LEE, ${ }^{1 *}$ Huang-Haur KUO ${ }^{1}$ AND Yue-Gau CHEN ${ }^{2}$ \\ ${ }^{1}$ Institute of Fisheries Science and ${ }^{2}$ Department of Geology, College of Science, \\ National Taiwan University, Taipei, Taiwan 106
}

\begin{abstract}
The discrimination between wild and released Taiwan abalone Haliotis diversicolor was performed by stable carbon isotope analysis. Abalone samples were collected from Mao Aw Gulf in north-eastern Taiwan. Live abalone and dead shells were collected by divers with an $80 \times 80 \mathrm{~cm}$ frame. The densities and amounts of wild and released abalone, as well as the survival rates of released abalone, in 1997 and 1998 were estimated. The age of the specimens was also determined from the specific temperature of each month and the inverse relationship between oxygen isotope values and temperatures. Results show that examining stable isotopic profiles proves to be a practical and feasible method for stock discrimination as well as density and abundance estimation. These data would be helpful in assessing the success of abalone culture and release programs, which aim to enhance this valuable marine resource.
\end{abstract}

KEY WORDS: abalone, carbon stable isotope, density and abundance estimation, Haliotis diversicolor, oxygen stable isotope, stable isotope analysis, survival rate.

\section{INTRODUCTION}

Abalone (Haliotis diversicolor) is one of the important commercial shell species in Taiwan, as well as a precious marine resource in the world. The distribution of abalone extends along Japan, south of Korea, south of China and Taiwan. Locally in Taiwan, abalone are mainly found along the northeastern, eastern and southern coast, as well as in the Penghu islands. ${ }^{1,2}$ In north-eastern Taiwan, abalone are chiefly caught by fishermen and poachers for sale and by amateur divers for pleasure; however, there is not yet any systematic collection of such catch data. Declining stock, as a result of exploitation of this species in the 1970s, has prompted the Taiwanese government to set up protection zones along the coast. In addition to conserving the abalone population, a department responsible for culturing and releasing abalone was also established for stock-enhancement purposes.

Studies on tagging and marking abalone had been performed but failed to obtain satisfactory

*Corresponding author: Tel: 886-22363-0846. Fax: 886-223633171. Email: 1812@ccms.ntu.edu.tw

Received 20 October 2000. Accepted 28 February 2002. results. In some cases, the tagging or marking made was far from ideal (RJ Tzeng, unpubl. data, 1996) and the marking may result in lower growth speed (RJ Tzeng, unpubl. data, 1997). Because it is difficult to distinguish between cultured and wild abalone in the sea, the effects of the release program remain unknown and the total abalone population has never been assessed.

Stable isotope profiles have been used to study environmental factors influencing the habitat of gastropod shells ${ }^{5}$ and fish, ${ }^{4}$ to explore the physical and metabolic processes of ecosystems ${ }^{5}$ and to examine dietary changes in birds, ${ }^{6}$ as well as for the identification and discrimination between populations of migratory birds ${ }^{9}$ and fish. ${ }^{8}$ The oxygen isotope values of shells vary with the temperature of the water and isotope values of water mass. It has been found that the higher the water temperature, the lower the oxygen isotope values will be. ${ }^{9}$ Generally speaking, the isotope values of seawater are more stable than those of freshwater because freshwater is usually subjected to geographic and hydrologic influences. Oxygen isotope values of seawater are also dependent on salinity. That is, the higher the salinity, the higher the oxygen isotope values. ${ }^{10}$ In addition, mineral crystallization can 
affect isotope values. In general, aragonite has higher oxygen isotope values than calcite. ${ }^{11}$

The carbon isotope values of shells also vary with the temperature of the water and isotope values of water mass. However, the effect of water temperature remains unclear. Some studies have found that the higher the water temperature, the higher the carbon isotope values will be, ${ }^{12-14}$ whereas other studies have revealed conflicting results. ${ }^{9}$ In some studies, water temperature was found to have little influence upon carbon isotope values. ${ }^{15}$ Apart from the possible effects of water temperature, the carbon isotope values of seawater are mainly influenced by an interaction between seawater and atmosphere, ${ }^{5}$ the photosynthesis of plankton, ${ }^{5}$ the decomposition of organisms, ${ }^{16}$ upwelling ${ }^{17,18}$ and influx of freshwater. ${ }^{3,19,20}$ The surface seawater usually has higher carbon isotope values because $\left[{ }^{12} \mathrm{C}\right]$, being much lighter than $\left[{ }^{13} \mathrm{C}\right]$, is consumed by plankton for photosynthesis. However, seawater at a deeper level has lower carbon isotope values because much $\left[{ }^{12} \mathrm{C}\right]$ is released by the decomposition of organisms. In upwelling areas, water mass at a deeper level is taken up to the surface. ${ }^{9,21}$ As a result, the carbon isotope values in upwelling areas are lower. In contrast, the carbon isotope values of freshwater are influenced by soil and plants. ${ }^{3,19,20}$ Like oxygen isotope values, the carbon isotope values of aragonite are usually higher than those of calcite. Some studies have shown that the carbon isotope values of fast-growing shells are lower than those of shells that are slower growing. ${ }^{22}$ Definitely, the physiology of living organisms can affect the fractionation of stable isotopic profiles, but the mechanism behind such influences is very complicated and much remains to be understood. ${ }^{3}$

The aim of the present study was to distinguish cultured abalone from wild abalone and to estimate stock size in Mao Aw Gulf, north-eastern Taiwan using stable carbon and oxygen isotope analyses with quadrate surveys.

\section{MATERIALS AND METHODS}

In order to estimate the density and abundance of abalone in Mao Aw Gulf, north-eastern Taiwan, the area of the gulf was divided into five experimental sites (Fig. 1). Site I is situated near the harbor, is shallow and is mainly made up of sand. Sites II and IV are at the opposite sides of the gulf and have many reefs. Site III is located at the estuary of the gulf and is relatively deeper. Towards the tip of the estuary, the water becomes shallower and there are many reefs. Finally, site V is at the outer left of the

Fig. 1 Sampling locations in Mao Aw Gulf, North-eastern Taiwan.

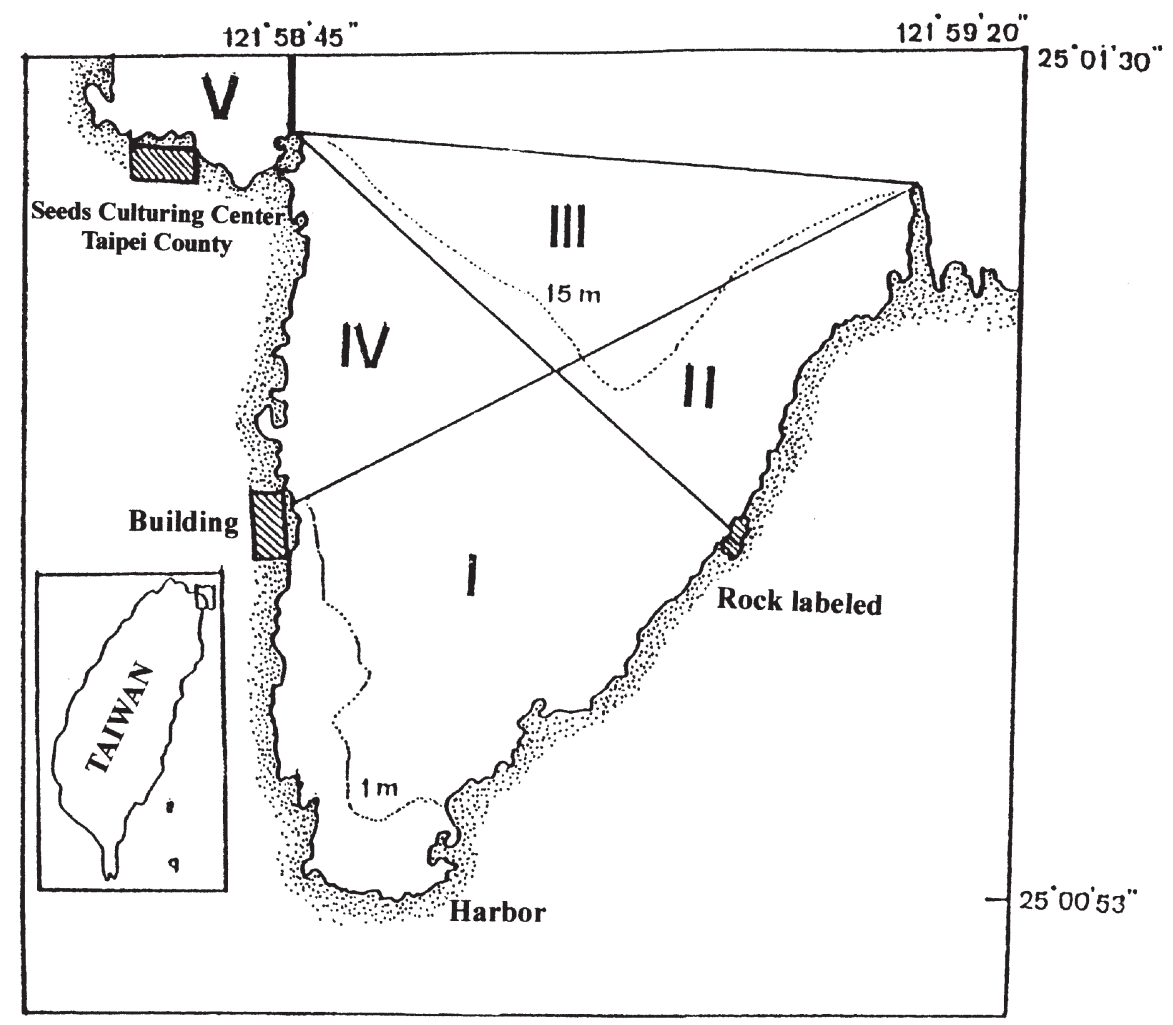


gulf, where there are also many reefs. Moreover, area less than $1 \mathrm{~m}$ in depth at site $\mathrm{I}^{1,2}$ and areas greater than $15 \mathrm{~m}$ in depth in sites II and $\mathrm{III}^{23}$ were excluded when estimating the total habitat area of abalone. This is because abalone are rarely found in these areas. Abalone were sampled monthly from July 1997 to September 1998, with the exception of August 1997, January-February 1998 and August 1998 because of bad weather. In addition, samples were taken in March 1999. At all five experimental sites, duplicate samples were taken from water of both greater and less than $5 \mathrm{~m}$ in depth. Live abalone and dead shells were collected by divers with an $80 \times 80 \mathrm{~cm}$ frame. Ten frames were used for each sampling. Overall, there were five samplings in 1997, six samplings in 1998 and one sampling in 1999. Environmental factors, including water temperature, salinity, $\mathrm{pH}$ value and dissolved oxygen were also measured at the same time as each sampling. The following formulae and variables were used for stock estimation.

Using the hypothsis that the distribution of wild and released abalone follows a binomial distribution, let $w_{i}, W_{i}$ and $p_{i}$ be the observed number per quadrant of wild abalone in the $i-t h$ site, the estimate of the total number of abalone and the proportion of wild abalone, respectively. Then, the point estimate of $W_{i}$ and the variance of the estimate were calculated as follows.

$$
\begin{gathered}
\hat{W}_{i}=\hat{Y}_{i} \hat{p}_{i} \\
\hat{V}\left(\hat{W}_{i}\right)=\hat{V}\left(\hat{Y}_{i} \hat{p}_{i}\right)=\hat{V}\left(\hat{Y}_{i}\right) \hat{V}\left(\hat{p}_{i}\right)+\hat{Y}_{i}^{2} \hat{V}\left(\hat{p}_{i}\right)+\hat{p}_{i}^{2} \hat{V}\left(\hat{Y}_{i}\right) \\
\hat{Y}_{i}=N_{i} \hat{\bar{y}}_{i}=N_{i}\left(\sum_{j=1}^{A_{i}} y_{i, j}\right) / n_{i} \\
\hat{V}\left(\hat{Y}_{i}\right)=\frac{N_{i}^{2} \hat{S}_{i}^{2}\left(N_{i}-n_{i}\right)}{n_{i} N_{i}} \\
\hat{p}_{i}=\frac{w_{i}}{n_{i}} \\
\hat{V}\left(\hat{p}_{i}\right)=\frac{\hat{p}_{i}\left(1-\hat{p}_{i}\right)}{n_{i}} \\
\text { when } N_{i} \gg>n_{i}, \hat{V}\left(\hat{Y}_{i}\right) \cong \frac{N_{i}^{2} \hat{S}_{i}^{2}}{n_{i}}
\end{gathered}
$$

where $i=1,2, \ldots 5$ site $j=1,2, \ldots A_{i}$ sampling time at the $i-t h$ site, $y_{i, j}$ is the observed live wild abalone at the $i-t h$ site and the $j-t h$ sampling time, $\hat{\bar{y}}$ is the mean density at the $i-t h$ site, $n_{i}$ is the sampling area at the $i-t h$ site, $\hat{S}_{i}^{2}$; is the variance at the $i-t h$ site, $N_{i}$ is the sea area at the $i-t h$ site and $\hat{Y}$; is the estimated wild stock abundance at the $i-t h$ site

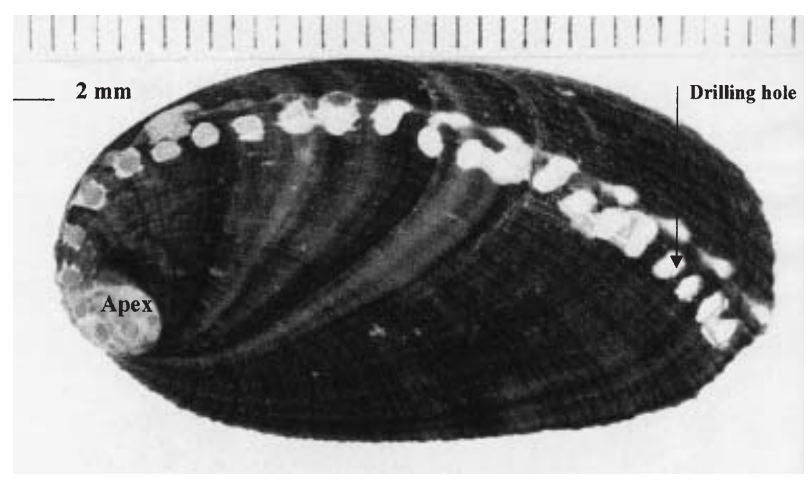

Fig. 2 Holes drilled along the growth line of abalone.

(i.e. the mean density of an $80 \times 80 \mathrm{~cm}$ frame multiples the sea area at the $i-t h$ site). Similarly, we can estimate the stock amount and variance of the released abalone.

As for sample preparation, shells were first scraped and then soaked in $10 \% \mathrm{NaClO}$ for $24 \mathrm{~h}$ to remove any encrusting organisms. Shells were then washed with $1 \mathrm{M} \mathrm{HCl}$ and rinsed with excluded ion water. When dry, the shells were drilled with a $0.5 \mathrm{~mm}$ dental burr (Fig. 2). Shell materials were taken from holes drilled parallel to the growth lines at intervals of $2 \mathrm{~mm}$ and, from each hole, $3-6 \mathrm{mg}$ powder was collected. ${ }^{3}$ The powder was reacted at $70^{\circ} \mathrm{C}$ with phosphoric acid and the evolved $\mathrm{CO}_{2}$ was analyzed on a Finnigan Delta plus mass spectrometer (Global Headquarters, San Jose, CA, USA). Carbon and oxygen isotope values are reported in standard permillage notation $(\delta)$ relative to the PDB carbonate standard, a Cretaceous belemnite (Belemnitella americana) from the Peedee Formation of South Carolina, USA, as defined by the following equation: ${ }^{6}$

$$
\delta=\left(R_{\text {sample }} / R_{\text {standard }}-1\right) \times 1000
$$

where $R$ is the mass ratio $\left(\left[{ }^{13} \mathrm{C}\right] /\left[{ }^{12} \mathrm{C}\right]\right.$ or $\left.\left[{ }^{18} \mathrm{O}\right] /\left[{ }^{16} \mathrm{O}\right]\right)$ of the sample or standard. Analytical precision of the reported measurements is $\pm 0.03 \%$ o ( $1 \mathrm{SD}$ ) or better. ${ }^{24}$

\section{RESULTS AND DISCUSSION}

\section{Stock discrimination}

The present study analyzed the stable carbon isotope profiles of abalone samples from the culturing pools (one specimen in April 1998, two specimens in June 1998 and one specimen in September 1998) and from the gulf (one specimen in September 1997, one specimen in April 1998, three 

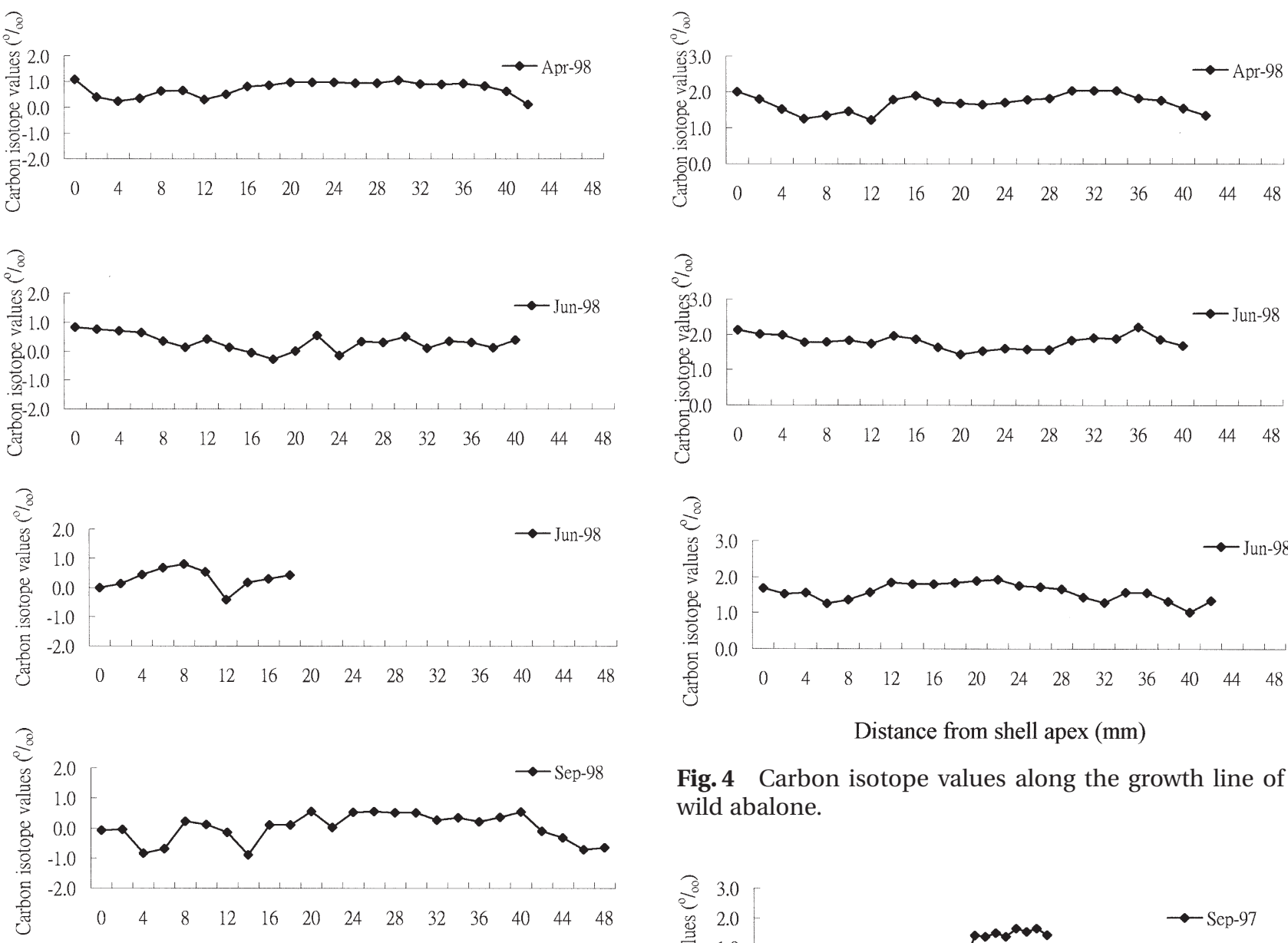

Distance from shell apex (mm)

Fig. 3 Carbon isotope values along the growth line of cultured abalone.

specimens in June 1998 and one specimen in March 1999). The $\delta\left[{ }^{13} \mathrm{C}\right]$ profiles of samples from the culturing pools showed that the mean carbon values were 0.72 in April 1998, 0.30 and 0.31 in June 1998 and 0.02 in September 1998. The highest value was 1.06 , whereas the lowest value was -0.89 (Fig. 3). In contrast, data from the gulf showed that the mean carbon values were 1.69 in April 1998 and 1.80 and 1.58 in June 1998. Among these three samples, the highest value was 2.17 and the lowest was 1.02 (Fig. 4). As for the three other specimens from the gulf, they showed a different pattern, revealing two stages in their profiles. The values near the shell apex were lower than those far from the shell apex. The mean carbon values near the shell apex were $0.53,0.52$ and 0.53 , whereas those far from the shell apex were 1.48, 1.85 and 1.69 for specimens obtained in September 1997, June 1998 and March 1999, respectively (Fig. 5). The mean stable carbon isotope values of all specimens were

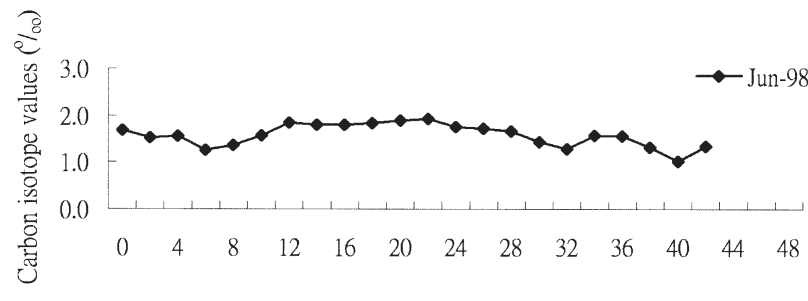

Distance from shell apex (mm)

Fig. 4 Carbon isotope values along the growth line of wild abalone.
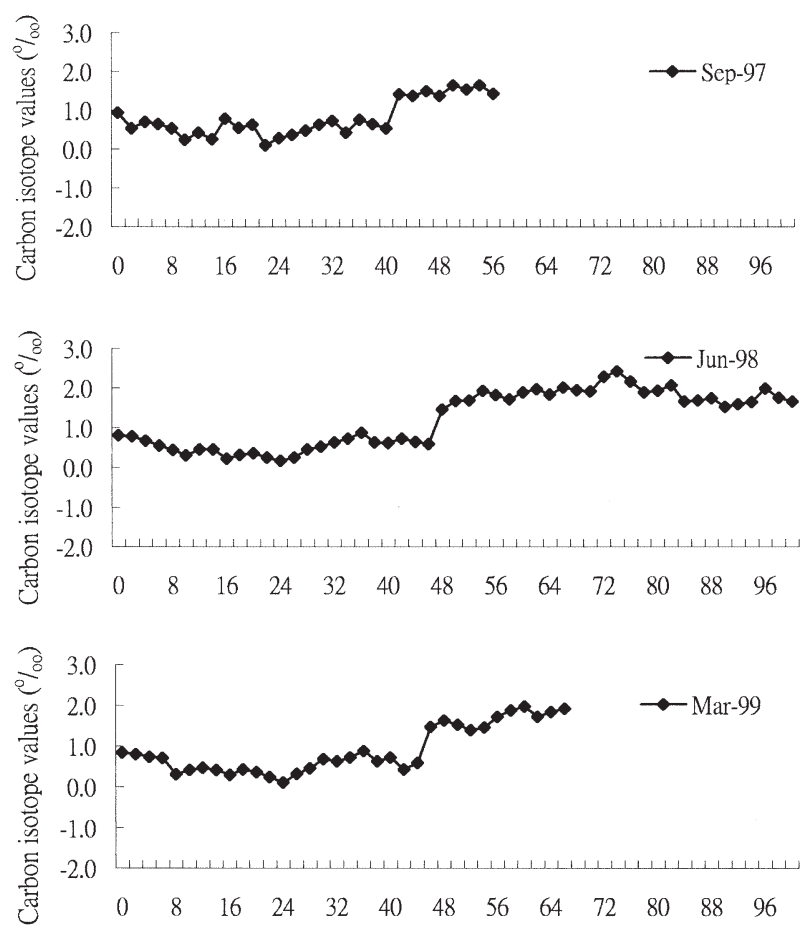

Distance from shell apex (mm)

Fig. 5 Carbon isotope values along the growth line of some abalone from the gulf show that the values near the shell apex were lower than those far from the shell apex. 


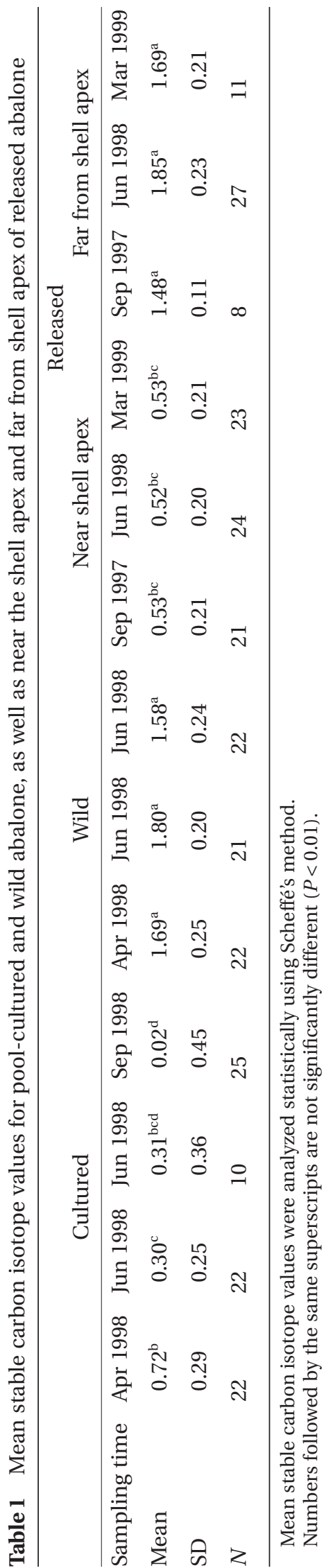

analyzed statistically using Scheffé's method. ${ }^{25}$ This showed that the carbon isotope values of the three wild abalone and those for samples taken far from the shell apex of three other abalone from the gulf are not significantly different $(P>0.01)$. However, values of the four pools culturing abalone and those for samples taken near the shell apex of the three other abalone from the gulf are different, the former six mean values being significantly different compared with the latter seven mean values $(P$ $<0.01$; Table 1). Therefore, we can conclude that the three other specimens from the gulf had lived in two different environments, first probably in the culturing pool and then in the sea. In addition, the average length near the shell apex, which showed lower carbon values, was $23 \mathrm{~mm}$ for these three specimens. This coincides with the length of hatchery produced abalone released to sea farms, which is generally between 20 and $30 \mathrm{~mm}$. The above data indicate that these three specimens had been cultured in pools and then released into the sea. In other words, they should be released abalone. Hence, the difference in carbon isotope values on the same specimen may shed light on its identity and life history. In the future, a simple verifying test should be undertaken. Some cultured abalone will be released to a protective area in the gulf for a period of time and then these abalone will be analyzed to determine whether the carbon isotope patterns along the growth line are similar to those shown in Fig. 5.

Furthermore, we can also distinguish released abalone from wild abalone by measuring their carbon isotope values at approximately $23 \mathrm{~mm}$ from the shell apex (Fig. 6). Lower values indicate that specimens are cultured abalone, whereas higher values indicate that they are wild abalone. Not only can stable carbon isotope analysis be used to distinguish cultured species from wild types, but it can also be performed with only a tiny amount of material and requires no external tagging or marking. Specifically, this method can effectively improve the previous tagging and/or marking studies (RJ Tzeng, unpubl. data, 1996, 1997). Thus, examining the carbon isotopic profiles proves to be a practical and feasible method for stock discrimination. Studies showing evidence of variation in isotope values for living organisms in different environments can be found in the literature..$^{18,19,26}$

\section{Abundance estimation}

There were four, eight, seven, two and seven individuals observed in 1997 for sites I-V, respectively, and nine, 29, 27, four and 43 in 1998, respectively. 


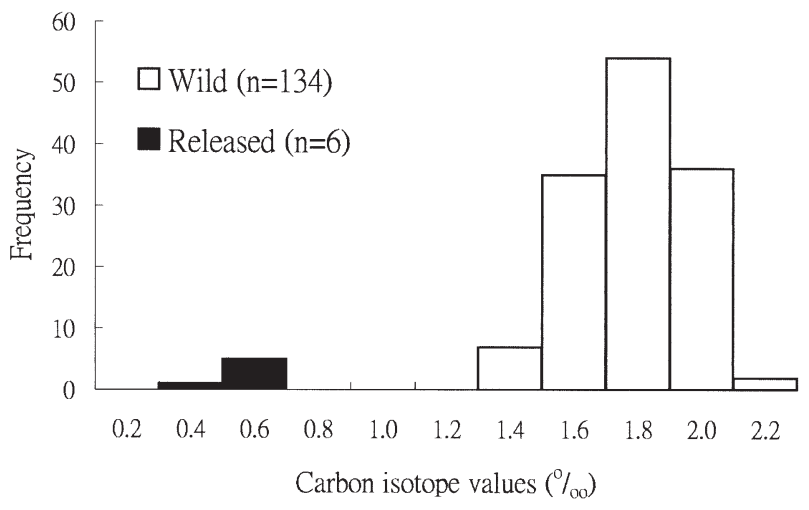

Fig. 6 Carbon isotope frequencies for wild and released abalone at sea.

Table 2 Estimated mean densities and amount of wild and released abalone in Mao Aw Gulf, North-eastern Taiwan in 1997

\begin{tabular}{lcrc}
\hline Site & $\begin{array}{c}\text { No. individuals } \\
\left(/ 0.64 \mathrm{~m}^{2}\right)\end{array}$ & $\begin{array}{c}\text { Sea area } \\
\left(\times 10^{4} \mathrm{~m}^{2}\right)\end{array}$ & $\begin{array}{c}\text { Amount of } \\
\text { abalone }\end{array}$ \\
\hline \multicolumn{4}{l}{ Wild abalone } \\
I & $0.150 \pm 0.150$ & 20.70464 & $48527 \pm 75762$ \\
II & $0.400 \pm 0.112$ & 6.98411 & $43651 \pm 12222$ \\
III & $0.350 \pm 0.109$ & 1.87547 & $10256 \pm 3194$ \\
IV & $0.100 \pm 0.069$ & 8.25347 & $12896 \pm 8898$ \\
V & $0.350 \pm 0.131$ & 3.50054 & $19144 \pm 7165$ \\
Total & $0.208 \pm 0.080$ & 41.31823 & $134473 \pm 103059$ \\
Released abalone & & - \\
I & $0.250 \pm 0.250$ & 20.70464 & $16176 \pm 22515$ \\
II & - & 6.98411 & - \\
III & - & 1.87547 & - \\
IV & - & 8.25347 & - \\
V & - & 3.50054 & $16176 \pm 14763$ \\
Total & $0.107 \pm 0.025$ & 41.31823 & \\
\hline
\end{tabular}

Data are the mean \pm SD.

In 1997, the estimated density per $0.64 \mathrm{~m}^{2}$ was 0.208 for wild abalone and 0.107 for released abalone. In addition, the estimated abundance was 134473 for wild abalone and 16176 for released abalone. Therefore, the total density and population of abalone in the gulf was 0.315 per $0.64 \mathrm{~m}^{2}$ and 150649 individuals (Table 2). Similarly, in 1998, the estimated density per $0.64 \mathrm{~m}^{2}$ was 0.507 for wild abalone and 0.032 for released abalone. In addition, the estimated abundance was 327390 for wild abalone and 20513 for released abalone. Thus, the total density and population of abalone in the gulf was 0.539 per $0.64 \mathrm{~m}^{2}$ and 347903 individuals (Table 3).

In 1997, the estimated abundance of released abalone over the total population in the gulf was approximately $10.74 \%$. Furthermore, compared with the 450000 previously released abalone (MS
Table 3 Estimated mean densities and amount of wild and released abalone in Mao Aw Gulf, North-eastern Taiwan in 1998

\begin{tabular}{|c|c|c|c|}
\hline Site & $\begin{array}{l}\text { No. individuals } \\
\quad\left(/ 0.64 \mathrm{~m}^{2}\right)\end{array}$ & $\begin{array}{l}\text { Sea area } \\
\left(\times 10^{4} \mathrm{~m}^{2}\right)\end{array}$ & $\begin{array}{l}\text { Amount of } \\
\text { abalone }\end{array}$ \\
\hline \multicolumn{4}{|c|}{ Wild abalone } \\
\hline I & $0.286 \pm 0.101$ & 20.70464 & $92524 \pm 61737$ \\
\hline II & $1.000 \pm 0.212$ & 6.98411 & $109127 \pm 30026$ \\
\hline III & $0.929 \pm 0.170$ & 1.87547 & $27224 \pm 7177$ \\
\hline IV & $0.143 \pm 0.067$ & 8.25347 & $18441 \pm 8640$ \\
\hline $\mathrm{V}$ & $1.464 \pm 0.270$ & 3.50054 & $80075 \pm 19721$ \\
\hline Total & $0.507 \pm 0.068$ & 41.31823 & $327390 \pm 113730$ \\
\hline \multicolumn{4}{|c|}{ Released abalone } \\
\hline $\mathrm{I}$ & $0.036 \pm 0.036$ & 20.70464 & $11646 \pm 9239$ \\
\hline II & $0.036 \pm 0.036$ & 6.98411 & $3929 \pm 1009$ \\
\hline III & $0.036 \pm 0.036$ & 1.87547 & $1055 \pm 290$ \\
\hline IV & - & 8.25347 & - \\
\hline $\mathrm{V}$ & $0.071 \pm 0.050$ & 3.50054 & $3883 \pm 815$ \\
\hline Total & $0.032 \pm 0.020$ & 41.31823 & $20513 \pm 7767$ \\
\hline
\end{tabular}

Data are the mean \pm SD.

Pan, pers. comm., 1999), the survival rate of released abalone was approximately $3.59 \%$. In 1998, the estimated abundance of released abalone over the total population in the gulf was approximately $5.90 \%$. Compared with the 400000 previously released abalone, the survival rate was approximately $5.13 \%$. Hence, the average survival rate of released abalone in these 2 years was approximately $4.36 \%$.

\section{Climatic changes}

The temperature of the gulf decreased from November 1997 to January 1998, increased from February 1998 to July 1998 and finally decreased again from August 1998 to January 1999, showing a seasonal periodic cycle. In addition, the local water temperature of the gulf showed a trend similar to that of the seasonal climatic variation. Although complete seasonal data for water temperature are unavailable, the changing trend of the air temperature serves as a helpful source of information for analysis (Fig. 7a).

Of the two specimens cultured between November 1998 and January 1999, their isotopic profiles were found to decrease with the rise in temperature and increase with the drop in temperature (Fig. $7 b, c)$. That is, when compared with the temperature profiles, it can be seen that the higher the temperature, the lower the oxygen values will be and vice versa. There exists an inverse relationship between temperature and oxygen isotope values. 

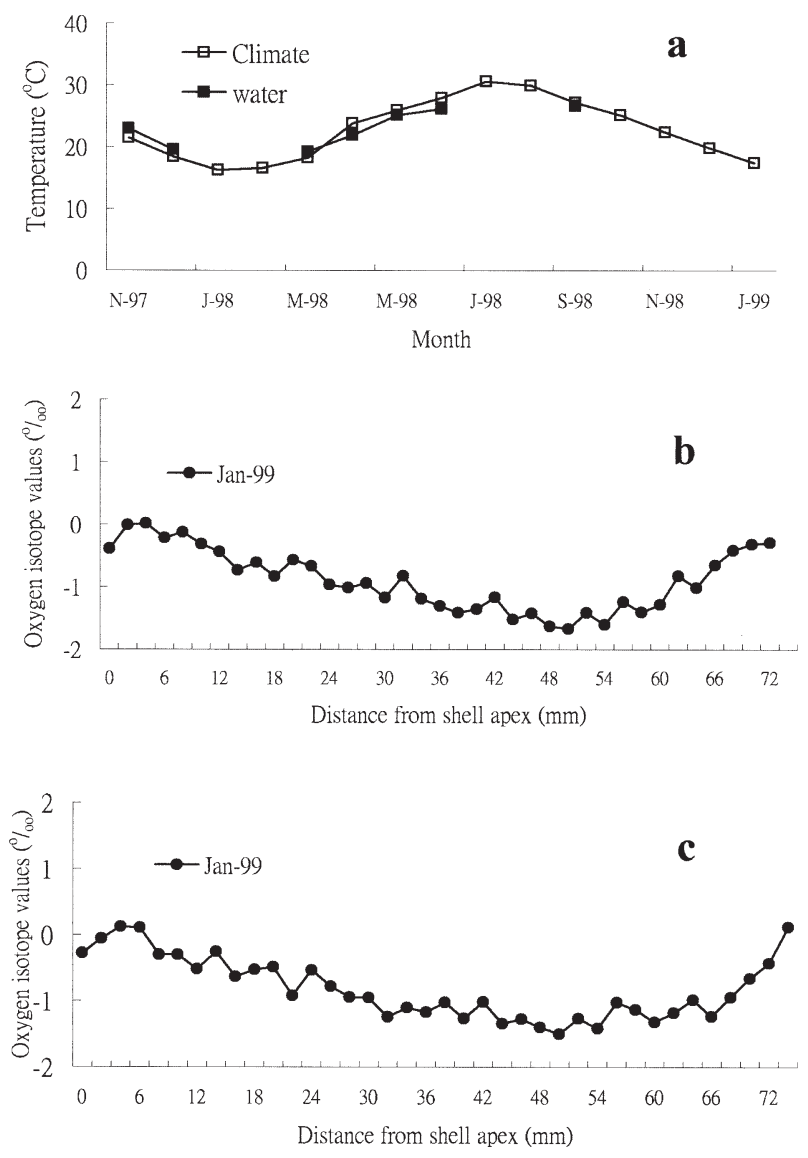

Fig. 7 Relationship between oxygen isotope values and temperatures. (a) Climate temperatures and local water temperatures from November 1997 to January 1999. (b,c) Oxygen isotope values along the growth line of two cultured abalone.

The effects of temperature on oxygen and carbon isotopes have been discussed by Grossman and $\mathrm{Ku}$. ${ }^{9}$ Therefore, on the basis of the specific temperature of each month and the inverse relationship between oxygen isotope values and temperatures, we can estimate the age of the specimens sampled. Using stable oxygen isotope analysis to estimate the ages of molluscs is usually read in studies of fossil gastropods. ${ }^{9,20,26}$ Among all released specimens from the gulf, the oldest specimen was estimated to be 3.24 years of age. This proves that some of the juvenile abalone released many years ago have survived.

The relationship between mean density and environmental factors at the five sites is shown in Fig. 8 . The relationship between mean density and $\mathrm{pH}$ values is positive (i.e. the higher the $\mathrm{pH}$ value, the higher the mean density will be). The coefficient of correlation $(r)$ for this relationship is 0.9073 $(P<0.05)$. However, the relationship between mean density and dissolved oxygen shows a negative
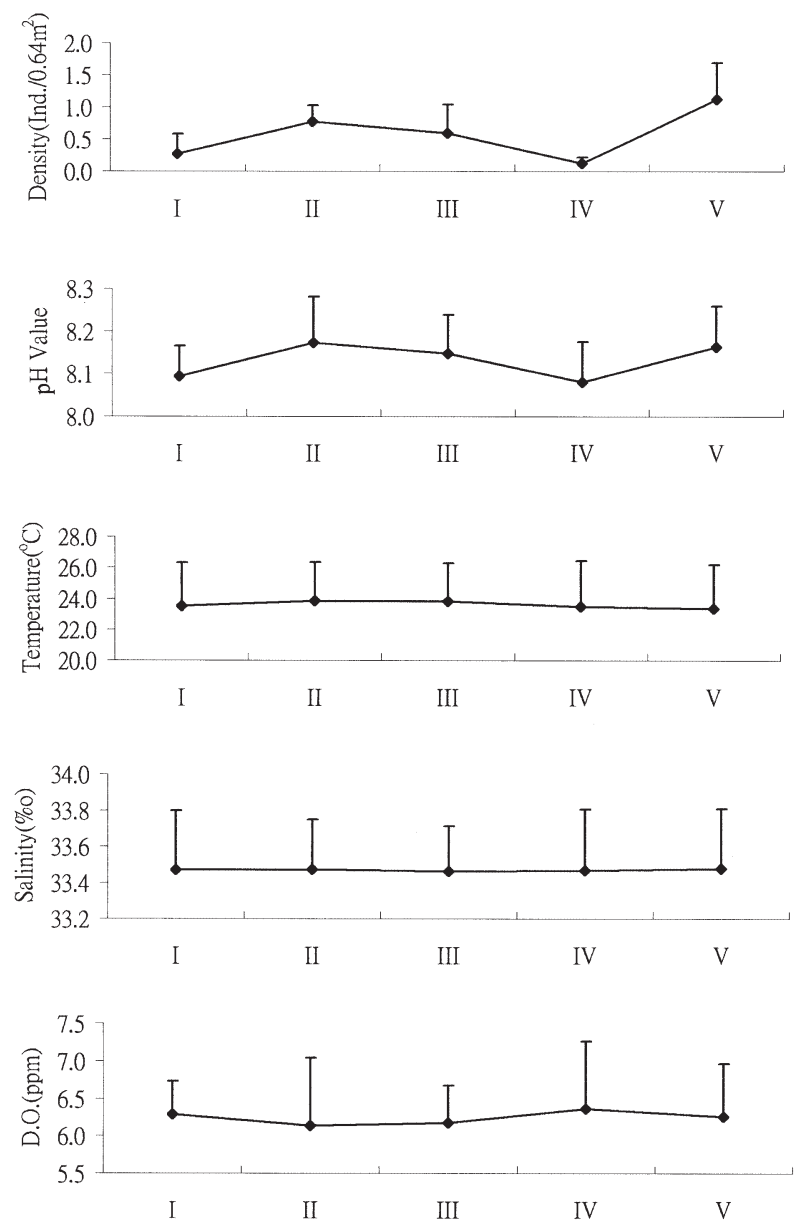

Fig. 8 Relationship between mean density and environmental factors at the five experimental sites.

trend (i.e. the higher the dissolved oxygen, the lower the mean density), with $r=-0.5844$, but the difference is not significant $(P>0.05)$. In addition, the relationship between mean density and temperature, as well as the relationship between mean density and salinity, also shows no significant trends.

To address the issue of declining stocks and with the purpose of enhancing abalone resources, many coastal district governments have been involved in the culture and release of abalone seeds. So far, the results of such efforts remain unknown because of the difficulty of stock estimation. In particular, it was difficult in the past to make any distinction between released and wild abalone. Nevertheless, such problems can now be overcome by using isotope analysis. Discrimination can be easily made between released and wild abalone by measuring their carbon isotope values at approximately $23 \mathrm{~mm}$ from the shell apex. In this way, the respective populations can also be estimated. 
Table 4 Carbon stable isotope values of water pumped into and drained from pools and seawater at $5 \mathrm{~m}$ depth

\begin{tabular}{llll}
\hline Replications & $\begin{array}{c}\text { Water } \\
\text { pumped } \\
\text { into pools }\end{array}$ & $\begin{array}{c}\text { Water } \\
\text { drained } \\
\text { from pools }\end{array}$ & $\begin{array}{c}\text { Seawater } \\
(5 \mathrm{~m} \text { depth) }\end{array}$ \\
\hline 1 & 0.25 & 0.27 & 0.23 \\
2 & 0.26 & 0.30 & 0.28 \\
3 & 0.19 & 0.20 & 0.21 \\
Mean \pm SD & $0.23 \pm 0.04$ & $0.26 \pm 0.05$ & $0.24 \pm 0.04$ \\
\hline
\end{tabular}

These data will be helpful in assessing the survival rate of released abalone and the success of such stock enhancement schemes.

For easy management of abalone resources in this area in the future, we intend to collect the catch and effort data of professional fishermen and amateur divers in order to estimate the natural mortality rate and fishing mortality rate.

In order to investigate why the carbon isotopes of abalone from culturing pools and those from the sea are different, we examined the carbon isotopes of the water pumped into and drained out from culturing pools, as well as seawater taken at a depth of $5 \mathrm{~m}$ and pumped into the culturing pools. The mean carbon isotope values of these three water samples were $0.23,0.26$ and 0.24 , respectively (Table 4). An Anova test showed that there were no significant differences among the three waters $(P=0.81>0.05)$. The present study also analyzed cultured abalone in June 1998, the growth speed of which was much lower. The carbon isotope values for these cultured abalone ranged from 0 to 1 and were similar to those of two other cultured abalone with faster growth (Fig. 3). Therefore, we conclude that the difference in carbon isotope values between cultured and wild abalone may not result from water isotope values of different places or different growth speeds for the two stocks. In addition, neither is difference in water temperatures a contributing factor. Although the variation in water temperatures over a short period of time at the culturing pools may be higher than that of seawater, over a longer stretch of time, the changing trend of water temperatures at culturing pools is similar to that of the sea. Hence, the oxygen isotope values should follow the same pattern. That is, the water temperatures should not be the cause for variations in carbon isotope values. What precisely accounts for such differences in carbon isotope values is worth further investigation. A better understanding may prove beneficial to the development of practical techniques in improving marking and releasing experiments.

\section{ACKNOWLEDGMENTS}

The authors thank two anonymous reviewers for their comments and correction of the manuscript, as well as thank Miss Judy MH Wu (KT Li Foundation for the Development of Science and Technology, Taipei, Taiwan), who corrected the English. We also thank Director MS Pan, Mr ML Lin and the staff of the abalone culturing and releasing center of Taipei County, as well as the Ya-Chaur Diving Company, for their assistance in sample collection. Financial support from the Council of Agriculture, Republic of China (87-AST-1.4-FID-05(15), 88-AST1.4-FID-03(24)) is also much appreciated.

\section{REFERENCES}

1. Chen JS, Wu JL. Investigation and assessment of abalone protecting area at Che-Cherg of Pyng Dong County. Taiwan Fisheries Bureau Specific Ser. 1 1986; 51-59 (translated into English from Chinese).

2. Huang SU. Investigation on released abalone at protecting area of Tai Dong County. Taiwan Fisheries Bureau Specific Ser. 1 1986; 61-69 (translated into English from Chinese).

3. Geary DH, Brieske TA, Bemis BE. The influence and interaction of temperature, salinity, and upwelling on the stable isotopic profiles of strombid gastropod shells. Palaios 1992; 7: 77-85.

4. Devereux I. Temperature measurements from oxygen isotope ratios of fish otoliths. Science 1967; 155: 1684-1685.

5. Peterson BJ, Fry B. Stable isotopes in ecosystem studies. Annu. Rev. Ecol. Syst. 1987; 18: 293-320.

6. Mizutani H, Fukuda M, Kabaya Y. ${ }^{13} \mathrm{C}$ and ${ }^{15} \mathrm{~N}$ enrichment factors of feathers of 11 species of adult birds. Ecology 1992; 73: 1391-1395.

7. Chamberlain CP, Blum JD, Holmes RT, Feng X, Sherry TW, Graves GR. The use of isotope tracers for identifying populations of migratory birds. Oecologia 1997; 109: 132-141.

8. Edmonds JS, Fletcher WJ. Stock discrimination of pilchards Sardinops sagax by stable isotope ratio analysis of otolith carbonate. Mar. Ecol. Prog. Ser. 1997; 152: 241-247.

9. Grossman EL, Ku TL. Oxygen and carbon isotopic fraction in biogenic aragonite: Temperature effects. Chem. Geol. 1986; 59: 59-74.

10. Epestein S, Mayeda T. Variation in ${ }^{18} \mathrm{O}$ content of waters from natural sources. Geochim. Cosmochim. Acta 1953; 4: 213-224.

11. Turner JV. Kinetic fractionation of C-13 during calcium carbonate precipitation. Geochim. Cosmochim. Acta 1982; 46: 1183-1192.

12. Sackett WM, Eckelmann WR, Bender ML, Be AWH. Temperature dependence of carbon isotope composition in marine plankton and sediments. Science 1965; 148: 235-237.

13. Degens ET, Duillard RRL, Sackett WM, Hellebust JA. Metabolic fractionation of carbon isotopes in marine plankton: 1. Temperature and respiration experiments. Deep Sea Res. 1968; 15: 1-9. 
14. Galimov EM. The Biological Fractionation of Isotopes. Academic Press, Orlando. 1985.

15. Emrich K, Ehhalt DH, Vogel JC. Carbon isotope fractionation during the precipitation of calcium carbonate. Earth Planet Sci. Lett. 1970; 8: 361-371.

16. Magaritz M, Holser WT. Carbon isotope shifts in Pennsylvanian seas. Am. J. Sci. 1990; 290: 977-994.

17. Killingley JS, Berger WH. Stable isotopes in a mollusk shell: Detection of upwelling events. Science 1979; 205: 186-188.

18. Jones DS, Allmon WD. Records of upwelling, seasonality and growth in stable-isotope profiles of Pliocene mollusk shells from Florida. Lethaia 1995; 28: 61-74.

19. Fritz P, Poplawski S. ${ }^{18} \mathrm{O}$ and ${ }^{13} \mathrm{C}$ in the shells of freshwater molluscs and their environments. Earth Planet Sci. Lett. 1974; 24: 91-98.

20. Buchardt B, Fritz P. Environmental isotopes as environmental and climatological indicators. In: Fritz, P, Fontes, JCH (eds). Handbook of Environmental Isotope Geochemistry, Vol. 1. Elsevier Scientific Publications, New York. 1980; 473-504.

21. Krantz DE, Kronick AT, Williams DF. A model for interpret- ing continental shelf hydrographic processes from the stable isotope and cadmium: Calcium profiles of scallop shells. Paleogeogr. Paleoclimatol. Paleoecol. 1988; 64: 123-140.

22. Wefer G, Killingley JS. Growth histories of strombid snails from Bermuda recorded in their ${ }^{18} \mathrm{O}$ and ${ }^{13} \mathrm{C}$ profiles. Mar. Biol. 1980; 60: 129-135.

23. Day RS. Fishery biology of abalone (Haliotis diversicolor) at Cherng Gong area in Tai Dong. Master Thesis, Institute of Fisheries Science, National Taiwan University, Taipei, 1988 (in Chinese).

24. Epstein S, Buchsbaum R, Lowenstam HA, Urey HC. Revised carbonate-water isotopic temperature scale. Bull. Geol. Soc. Am. 1953; 64: 1315-1326.

25. Sokal RR, Rohlf FJ. Biometry: The Principles and Practice of Statistics in Biological Research, 3rd edn. WH Freeman, New York. 1995.

26. Krantz DE, Williams DF, Jones DS. Ecological and paleoenvironmental information using stable isotope profiles from living and fossil molluscs. Paleogeogr. Paleoclimatol. Paleoecol. 1987; 58: 249-266. 